\title{
Influence of Soil Quality for Yield and Biometric Features of Sida hermaphrodita L. Rusby
}

\author{
Mariusz Matyka*, Jan Kuś \\ Department of Systems and Economics of Crop Production, Institute of Soil Science and Plant Cultivation \\ - State Research Institute in Puławy, Puławy, Poland
}

Received: 2 October 2017

Accepted: 3 December 2017

\begin{abstract}
Although the domain role of agriculture is food production, a part of agricultural land has always been devoted to non-food products, mainly within the framework of emerging technologies. One of the plants that can be used for various non-food purposes is Virginia mallow (Sida hermaphrodita L. Rusby). Following this study it was found that Sida hermaphrodita yields less on poor soil and on soils of good quality, but is too heavy. This plant has best yields on good soils with proper water-air relations. Nevertheless, good yields were also obtained on poorer and medium-quality soils. This is particularly important from the standpoint of competition for land resources between production for food and non-food products. Achieving yield at $1-2 \mathrm{~kg} \mathrm{DM}\left(\mathrm{m}^{2}\right)^{-1}$ is possible in the case of plants that grow from 16 to 24 shoots for stumps with a diameter of $11-13 \mathrm{~mm}$ and a height of 2.2-2.6 $\mathrm{m}$.
\end{abstract}

Keywords: Virginia mallow, biomass, yielding, biometric features, soil quality

\section{Introduction}

Although the domain role of agriculture is food production, a part of agricultural land has always been devoted to non-food products, mainly within the framework of emerging technologies. Such uses include the production of bioenergy and various biomaterials [1]. One of the plants that can be used for various nonfood purposes is Virginia mallow (Sida hermaphrodita L. Rusby). This species is a polycarpic perennial herb of open, moist, sunny to partly shaded riverine habitats. The shoots emerge from the soil in April from buds at the base of the previous year's stems and from the ends of numerous radiating rhizomes. Many large populations possibly are clonal. Flowering begins in early August

*e-mail: mariuszmatyka@iung.pulawy.pl and continues until a hard frost occurs [2]. The number of shoots after several years of cultivating can exceed $30-40$ units. Shoots reach a height of 200-400 cm and a diameter of 5-30 mm, they dry in autumn after the end of vegetation. Depending on field density and the method of establishing the plantation, soil and weather conditions, fertilization level, and average yields of Sida, just from

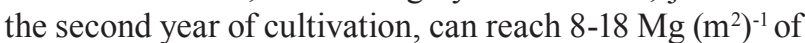
dry matter [3-10]. The level of obtained yields determines the economic and environmental efficiency cultivation and use of Virginia mallow biomass [11-13].

Non-food crops cultivation should not be competitive with food and fodder species having a high yield on fertile, heavy enough soil. In this condition particular importance is gained by researching crop species able to produce a satisfactory yield on light soil, for the choice of cultivations in this class of soil food and fodder plants is not wide. Those poor areas most often were excluded 
from cultivation for a long time, usually transformed into marginal land. Virginia fanpetals is one of the perennial species adjusted to over 10 years of cultivation tolerant to soil of low quality, low organic matter content, and low nutrient levels [14-15].

Initially, Virginia mallow was used as a fibrous, fodder, and melliferous plant. Recently, it has become popular as an energy crop due to the high yield per unit area. Fresh matter of Virginia mallow is a good substrate for biogas production. It possesses high dry matter content and suitable $\mathrm{C} / \mathrm{N}$ ratio. Sida hermaphrodita should be considered as a potential species for methane production due to its high yield, as well as relatively high biogas and methane yields [16]. Dry matter of this species is also very good as solid biofuel. It has low water content and high lower heating value $[4,17]$. In addition, Sida can be used for reclamation of soils contaminated with pesticides and heavy metals and reclamation of post-industrial areas [6, 18-20]. In addition, inline plantings of Virginia mallow can be used as biological acoustic screens [21], and Sida biomass can be considered a full-value material purposed for manufacturing particle boards [22].

Our paper presents the relationship between the quality of soil and yield as well as the biometrics features of Virginia mallow (Sida hermaphrodita).

\section{Materials and Methods}

The one factor experiment was established in 2007, which was treated as the year of compensatory and obtained yield was used for mulching carp, which serves to protect against frost in winter and the presented results concern the years 2008-2015. The long-term experiment was located in the experimental station IUNG-PIB in

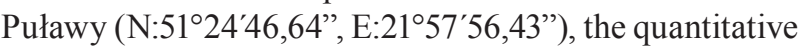

experimental factor was the differing soil conditions. The experiment considered the following soils:

A: fen brown soil with mechanical composition of ordinary dust.

B: brown soil, light sandy loam on poor sandy loam.

$\mathrm{C}$ : brown soil generated from loess.

D: brown soil, light sandy loam on heavy loam.

E: brown soil, light loam on heavy loam.

F: black soil, medium loam on heavy loam.

Part of the same experimental facility included research on Miscanthus x giganteus [23].

Sida hermaphrodita crops in the number of 3 pieces were planted on microplot at area $1.5 \mathrm{~m}^{2}$ and depth of $1.5 \mathrm{~m}$, for which the bottom was local bedrock (Fig. 1). Microplots were filled in the years 1973-1974 with soils collected by levels from natural soil. Layers of soil to fill the microplots were removed and collected separately from the individual levels. During the filling of the plots natural arrangement of the soil layers was preserved [24]. Each of the soils considered in the experiment were found in triplicate $\left(3 \times 1.5 \mathrm{~m}^{2}\right)$. In the years preceding the establishment of the experiment, the Sida hermaphrodita object was used in the research for typical agricultural crops, mainly cereals.

Every year we applied chemical protection against the fungus Sclerotinia sclerotiorum. Spraying was carried out in the first half of June by using Horizon 250 EW fungicide at concentration $0.018 \%$. In the experiment we have been used the following doses of mineral fertilizers: N-120 kg.ha-1, P-30 kg.ha-1, $\mathrm{K}-80 \mathrm{~kg} \cdot \mathrm{ha}^{-1}, \mathrm{Mg}-5 \mathrm{~kg} \cdot \mathrm{ha}^{-1}$, and S-10 kg$\cdot \mathrm{ha}^{-1}$. Harvest of plants and sampling for analysis was carried out after the growing season during one day depending on the year in November-December. The yield level, biometric features, and share of dry matter was described for all harvested plants individually.

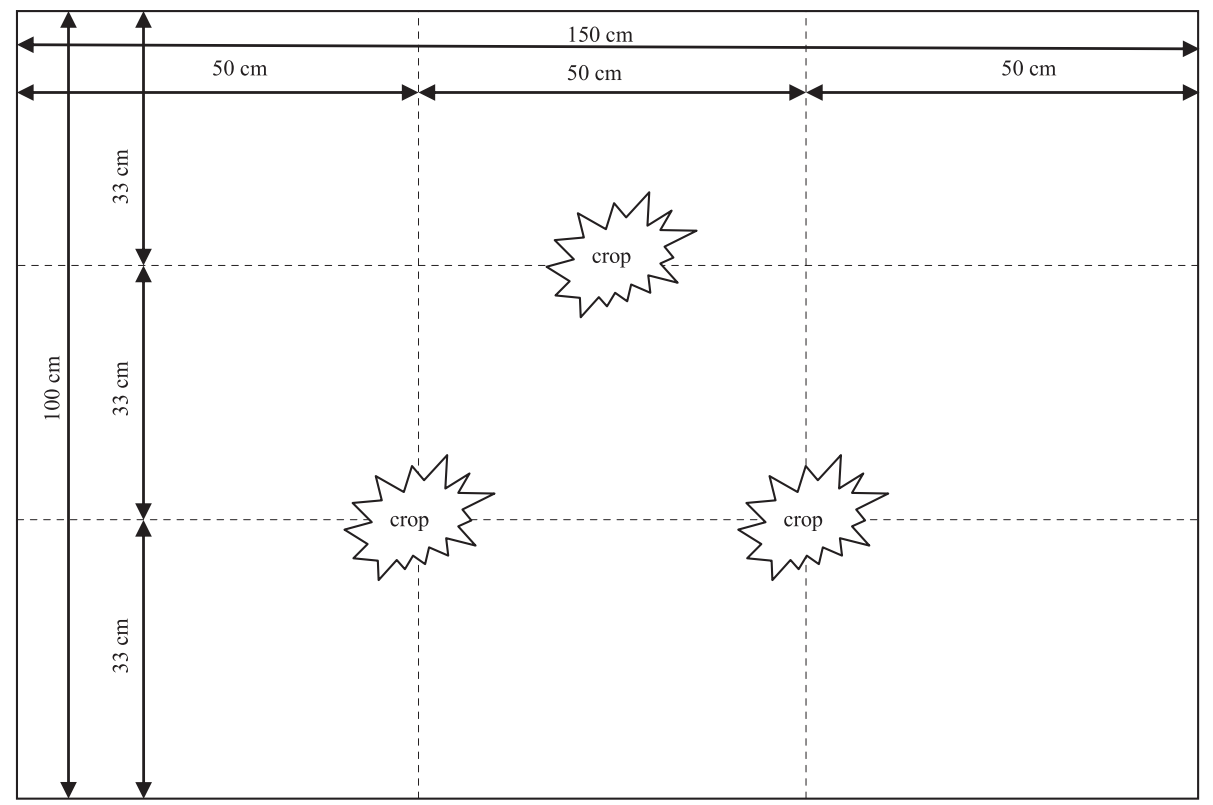

Fig. 1. Scheme of Sida hermaphrodita crops arrangement on microplot. 
Table 1. Weather conditions of the experiment on the background of long-term average.

\begin{tabular}{|c|c|c|c|c|c|c|c|c|c|c|c|c|c|}
\hline Month & I & II & III & IV & V & VI & VII & VIII & IX & $\mathrm{X}$ & XI & XII & Average for year \\
\hline \multicolumn{14}{|c|}{ Temperature } \\
\hline 2008 & 0.9 & 2.6 & 3.9 & 9.4 & 13.5 & 18.2 & 18.8 & 18.6 & 12.5 & 9.9 & 5.1 & 1.4 & 9.6 \\
\hline 2009 & -2.6 & -0.7 & 2.2 & 11.0 & 13.7 & 16.6 & 20.1 & 18.4 & 14.8 & 6.8 & 5.3 & -1.1 & 8.7 \\
\hline 2010 & -8.4 & -2.0 & 3.2 & 9.3 & 14.3 & 18.3 & 22.1 & 20.2 & 12.2 & 5.5 & 6.5 & -4.6 & 8.1 \\
\hline 2011 & $-0,5$ & $-3,7$ & 3,3 & 11,0 & 14,3 & 19,0 & 18,3 & 18,9 & 15,1 & 8,1 & 2,8 & 2,2 & 9,1 \\
\hline 2012 & $-1,3$ & $-6,5$ & 4,9 & 9,9 & 15,6 & 17,7 & 21,4 & 19,0 & 15,0 & 8,3 & 5,7 & $-3,1$ & 8,9 \\
\hline 2013 & $-3,4$ & $-0,6$ & $-1,5$ & 8,7 & 15,6 & 18,7 & 19,8 & 19,7 & 12,1 & 10,3 & 5,8 & 2,0 & 8,9 \\
\hline 2014 & $-2,2$ & 1,9 & 6,7 & 10,8 & 14,3 & 16,4 & 20,9 & 18,3 & 14,6 & 9,5 & 4,9 & 0,6 & 9,7 \\
\hline 2015 & 1,3 & 1 & 5,1 & 8,6 & 13,5 & 17,9 & 20,4 & 22,6 & 15,3 & 7,0 & 5,2 & 4,0 & 10,2 \\
\hline $\begin{array}{c}\text { Average for years } \\
1871-2008\end{array}$ & -3.3 & -2.3 & 1.6 & 7.8 & 13.5 & 16.8 & 18.5 & 17.4 & 13.3 & 8.0 & 2.8 & -1.3 & 7.7 \\
\hline \multicolumn{14}{|c|}{ Rainfall in mm } \\
\hline 2008 & 43 & 16 & 52 & 46 & 95 & 77 & 92 & 82 & 69 & 44 & 21 & 41 & 679 \\
\hline 2009 & 24 & 38 & 67 & 1 & 71 & 119 & 67 & 73 & 27 & 88 & 47 & 55 & 676 \\
\hline 2010 & 29 & 35 & 25 & 17 & 107 & 58 & 54 & 89 & 113 & 14 & 66 & 32 & 638 \\
\hline 2011 & 25 & 13 & 12 & 24 & 60 & 51 & 210 & 41 & 6 & 21 & 0 & 29 & 492 \\
\hline 2012 & 31 & 16 & 20 & 32 & 35 & 69 & 114 & 84 & 19 & 72 & 28 & 21 & 541 \\
\hline 2013 & 40 & 29 & 34 & 37 & 85 & 82 & 31 & 7 & 48 & 5 & 45 & 11 & 454 \\
\hline 2014 & 39 & 19 & 31 & 58 & 172 & 95 & 66 & 117 & 14 & 22 & 21 & 36 & 690 \\
\hline 2015 & 55 & 10 & 46 & 29 & 112 & 32 & 55 & 4 & 126 & 30 & 47 & 25 & 571 \\
\hline $\begin{array}{c}\text { Average for years } \\
1871-2008\end{array}$ & 31 & 30 & 30 & 40 & 57 & 70 & 84 & 75 & 51 & 43 & 39 & 37 & 587 \\
\hline
\end{tabular}

The years of conducting the experiment were characterized by different weather conditions (Table 1).

Statistical analysis of results was performed using
Statistica 9.0 software. During the preparation of the database from the analysis we removed the outliers and extremes data, and the level of significance adopted

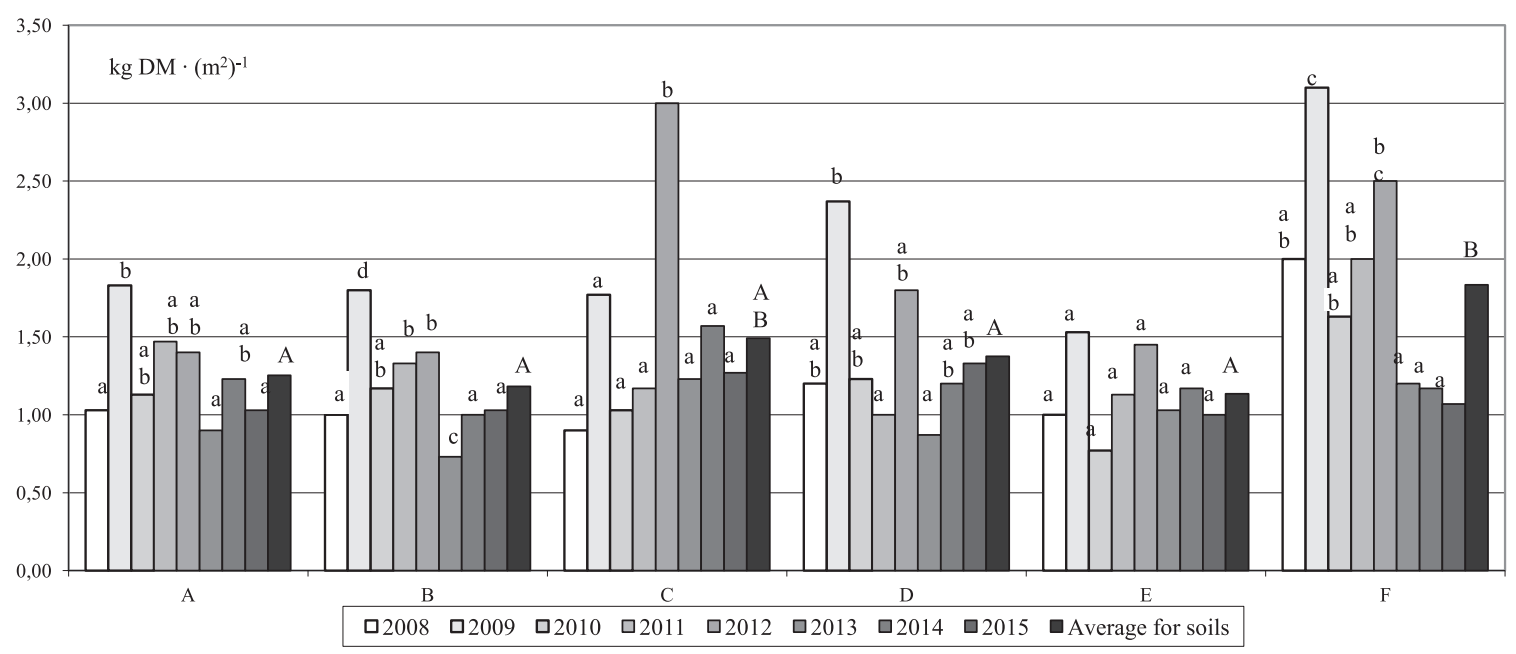

Fig. 2. Variation of dry matter yield $\left(\mathrm{kg} \mathrm{DM}\left(\mathrm{m}^{2}\right)^{-1}\right)$ of Sida hermaphrodita depending on the soils and years.

* Explanations: data marked with the same letters do not differ significantly at $\alpha=0.05$; the significance of differences was calculated separately for each soil and for the mean values (for soil and years). 
Table 2. Yield and biometric features of Sida hermaphrodita in different soils (average for the years 2008-2015).

\begin{tabular}{|c|c|c|c|c|}
\hline $\begin{array}{c}\text { Types of } \\
\text { soil }\end{array}$ & $\begin{array}{c}\text { Yield } \\
(\mathrm{kg} \mathrm{DM} \cdot \\
\left.\left(\mathrm{m}^{2}\right)^{-1}\right)\end{array}$ & $\begin{array}{c}\text { Number } \\
\text { of shoots } \\
\text { for plant }\end{array}$ & $\begin{array}{c}\text { Plant } \\
\text { height } \\
(\mathrm{m})\end{array}$ & $\begin{array}{c}\text { Shoot } \\
\text { diameter } \\
(\mathrm{mm})\end{array}$ \\
\hline $\mathrm{A}$ & $1.3 \mathrm{a}^{*}$ & $17 \mathrm{a}$ & $2.1 \mathrm{a}$ & $11.3 \mathrm{a}$ \\
\hline $\mathrm{B}$ & $1.2 \mathrm{a}$ & $17 \mathrm{a}$ & $2.1 \mathrm{a}$ & $11.2 \mathrm{a}$ \\
\hline $\mathrm{C}$ & $1.5 \mathrm{ab}$ & $20 \mathrm{ab}$ & $2.2 \mathrm{ab}$ & $11.7 \mathrm{ab}$ \\
\hline $\mathrm{D}$ & $1.4 \mathrm{a}$ & $19 \mathrm{ab}$ & $2.1 \mathrm{a}$ & $11.1 \mathrm{a}$ \\
\hline $\mathrm{E}$ & $1.1 \mathrm{a}$ & $16 \mathrm{a}$ & $2.2 \mathrm{a}$ & $11.8 \mathrm{ab}$ \\
\hline F & $1.8 \mathrm{~b}$ & $21 \mathrm{~b}$ & $2.4 \mathrm{~b}$ & $12.4 \mathrm{~b}$ \\
\hline Average & 1.4 & 18 & 2.2 & 11.6 \\
\hline
\end{tabular}

*Explanations: data marked with the same letters do not differ significantly at $\alpha=0.05$

for analysis was $p=0.05$. To determine the significance of differences we used the analysis of variance for a single factor, detailed by NIR test performed post hoc. Cluster analysis was performed by using the method of k-means, and the regression equation was performed using the "backwards step" method. Variables in the cluster analysis and the regression equation included the yield of dry matter (dependent variable in the regression analysis), number of shoots for a plant, plant height, shoot diameter and the share of dry mass. Modeling of yield depending on the selected Sida hermaphrodita biometric features made by using neural networks, which are the part of a new statistical method known as "data mining."

\section{Results and Discussion}

Obtained results showed that Sida hermaphrodita yields have a high range of variation between years and soils (Fig. 2, Tables 2-3). In the analyzed years, the highest yields were obtained in the brown soil generated from loess (C) and in black soil building from medium loam on heavy loam (F). The lowest yields were obtained in brown soil building from light loam on heavy loam (E), and brown soil building from light sandy loam on poorly sandy loam (B). Also, cluster analysis performed for the soils, taking account the obtained yield confirms this division (Table 5). The analysis showed that Sida hermaphrodita yields less in poor soil (B) and in soils of good quality, but too heavy $(\mathrm{E}, \mathrm{F})$. In the case of soil B, the low level of obtained yields can be explained by low ability to retain water, which is one of the most important yield factors. Soil E is characterized by a large share of floating fraction that can also negatively influence the soil air-water relationship, especially in periods of high intensity of rainfall. In light of the obtained results we should note that most suitable for the Sida hermaphrodita cultivation are soils of better quality but not too heavy.

Statistical analysis of the significance of differences also indicates that the obtained yields differ significantly
Table 3. Yield and biometric features of Sida hermaphrodita in different years (average for soils).

\begin{tabular}{|c|c|c|c|c|}
\hline Year & $\begin{array}{c}\text { Yield } \\
\left(\begin{array}{c}\mathrm{kg} \mathrm{DM} \cdot \\
\left.\left(\mathrm{m}^{2}\right)^{-1}\right)\end{array}\right.\end{array}$ & $\begin{array}{c}\text { Number } \\
\text { of shoots } \\
\text { for plant }\end{array}$ & $\begin{array}{c}\text { Plant } \\
\text { height } \\
(\mathrm{m})\end{array}$ & $\begin{array}{c}\text { Shoot } \\
\text { diameter } \\
(\mathrm{mm})\end{array}$ \\
\hline 2008 & $1.2 \mathrm{a}^{*}$ & $15 \mathrm{ab}$ & $2.2 \mathrm{ab}$ & $12.8 \mathrm{bc}$ \\
\hline 2009 & $2.1 \mathrm{~b}$ & $14 \mathrm{a}$ & $2.7 \mathrm{e}$ & $13.5 \mathrm{c}$ \\
\hline 2010 & $1.2 \mathrm{a}$ & $15 \mathrm{ab}$ & $2.4 \mathrm{c}$ & $12.4 \mathrm{~b}$ \\
\hline 2011 & $1.4 \mathrm{a}$ & $19 \mathrm{bc}$ & $2.1 \mathrm{a}$ & $11.1 \mathrm{a}$ \\
\hline 2012 & $1.9 \mathrm{~b}$ & $26 \mathrm{~d}$ & $1.7 \mathrm{~d}$ & $10.5 \mathrm{a}$ \\
\hline 2013 & $1.0 \mathrm{a}$ & $17 \mathrm{abc}$ & $2.0 \mathrm{a}$ & $10.7 \mathrm{a}$ \\
\hline 2014 & $1.2 \mathrm{a}$ & $18 \mathrm{abc}$ & $2.3 \mathrm{bc}$ & $11.1 \mathrm{a}$ \\
\hline 2015 & $1.1 \mathrm{a}$ & $21 \mathrm{c}$ & $2.1 \mathrm{a}$ & $10.6 \mathrm{a}$ \\
\hline Average & 1.4 & 18 & 2.2 & 11.6 \\
\hline
\end{tabular}

*Explanations: data marked with the same letters do not differ significantly at $\alpha=0.05$

depending on the soil (Table 2). The observed trends for the average of the 8 years (2008-2015) were also reflected in the observations for each year (Fig. 2). In addition, they conclude that Sida hermaphrodita yields differ between years in what is largely conditioned by weather conditions (Table 1). The lowest yields of Virginia mallow were obtained in the 2013 and 2015 years, which was characterized by the unfavorable distribution of rainfall and high temperature in the vegetation period. Reducing crop yields in the 2013 year of the study can be explained by a significantly more frosty March 2013, when the average monthly temperature was almost twice lower than the average for years 1871-2008. This is probably what caused the weakening of the plants and delayed the vegetation period. The highest yields were obtained in 2009 and 2012, when the course of the weather was very favorable. The number and distribution of rainfall and temperature conditions in the following months have allowed the disclosure of yield potential of Virginia mallow.

In experiments conducted in southeastern Poland, dry matter yield of Sida hermaphrodita depending of soil quality, nitrogen and phosphorus fertilization levels, and the year of cultivation ranged from about 2 to $17 \mathrm{Mg} \mathrm{DM} \mathrm{ha}^{-1}[4,12,14,25]$. The other hand in the experiment established in different parts of Poland yields were at a level 4-19 Mg DM ha-1 [10, 26-27]. In Lithuania the yield of Virginia mallow fluctuated between 4.7 and 7.5 $\mathrm{Mg} \mathrm{DM} \mathrm{ha}^{-1}$ [28].

A substantial degree of variability depending on soil and year also characterized the biometric features of Sida hermaphrodita (Tables 2-3). The most preferred values of biometric features were characterized by plants growing on brown soil generated from loess (C) and in black soil building from medium loam on heavy loam (F). They had the largest number of shoots from plants with the highest diameter and height (Table 2). Furthermore, in the 
statistical analysis for yield and biometric features these soils were placed in the same cluster. Plants cultivated on other soils were characterized by worse values and relationships of evaluated biometric features. They had generally the lowest number of shoots from plants, with low height and diameter.

Obtained results indicate that with the development of plantations relationships between biometric features have changed (Table 3 ). In the first years of vegetation (2008-2010), Virginia mallow created fewer shoots, but with larger diameter and height. In the following years (2011-2015) the plants created more shoots, but they were lower and have a smaller diameter.

In other experiments shoots of Sida hermaphrodita reached 2.6-3.2 $\mathrm{m}$ height and 13.0-19.8 $\mathrm{mm}$ diameter, whereas the crops created $15-22$ shoots $[4,12,25]$.

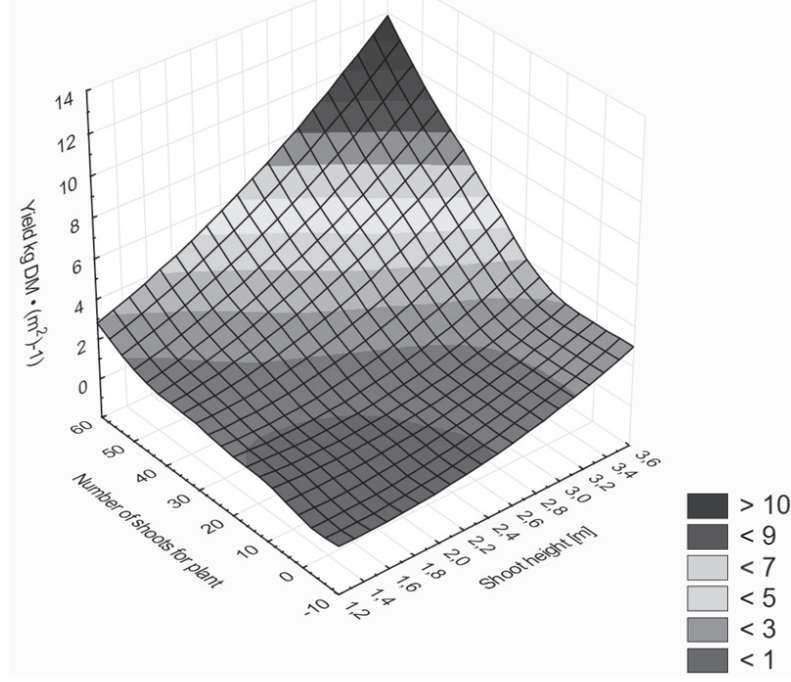

Fig. 3. Yield model for Sida hermaphrodita determined by number of shoots and their height.

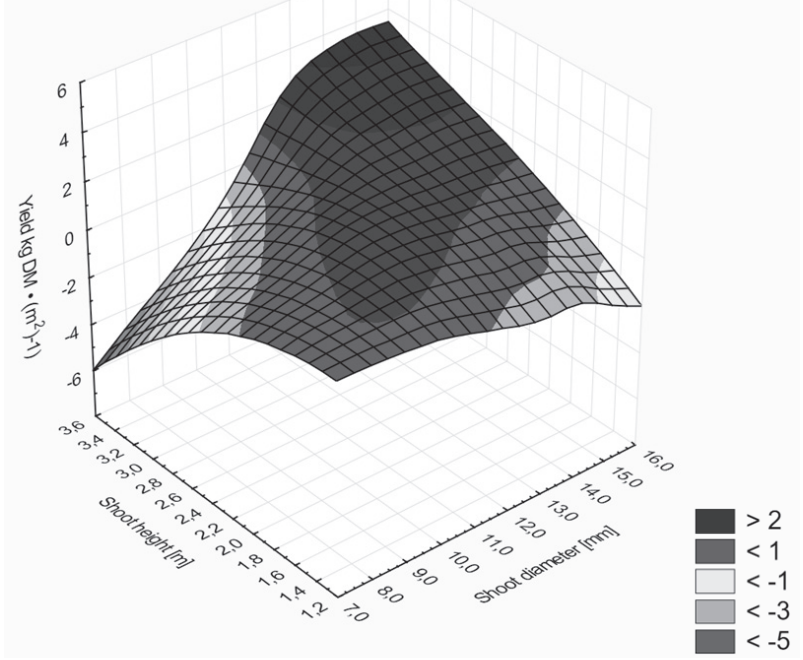

Fig. 4. Yield model for Sida hermaphrodita determined by shoot diameter and their height.
Table 4. Correlation coefficient $|\mathrm{r}|$ between the yield of Sida hermaphrodita $\left(\mathrm{kg} \mathrm{DM}\left(\mathrm{m}^{2}\right)^{-1}\right)$ and selected biometric features in different soils (average of the years 2008-2015).

\begin{tabular}{|c|c|c|c|c|}
\hline $\begin{array}{c}\text { Types of } \\
\text { soil }\end{array}$ & $\begin{array}{c}\text { The share } \\
\text { of dry } \\
\text { mass (\%) }\end{array}$ & $\begin{array}{c}\text { Number } \\
\text { of shoots } \\
\text { for plant }\end{array}$ & $\begin{array}{c}\text { Plant } \\
\text { height } \\
(\mathrm{m})\end{array}$ & $\begin{array}{c}\text { Shoot } \\
\text { diameter } \\
(\mathrm{mm})\end{array}$ \\
\hline A & 0.00 & 0.33 & $0.53^{*}$ & $0.47^{*}$ \\
\hline B & $-0.47^{*}$ & -0.26 & $0.63^{*}$ & $0.62^{*}$ \\
\hline C & 0.20 & $0.80^{*}$ & 0.05 & -0.12 \\
\hline D & -0.06 & $0.53^{*}$ & $0.58^{*}$ & 0.35 \\
\hline E & 0.16 & $0.80^{*}$ & 0.29 & -0.04 \\
\hline F & -0.34 & $0.48^{*}$ & 0.27 & $0.51^{*}$ \\
\hline $\begin{array}{c}\text { For all } \\
\text { soils }\end{array}$ & & & & \\
\hline
\end{tabular}

* correlations significant for $\alpha<0.05$

\section{Relationships between Yield and BiometricFeatures}

Correlation analysis shows that the DM yield of Sida hermaphrodita is dependent on other biometric features in different soils (Table 4). But the vast majority have the strongest relationship between DM yield and the share of dry mass, number of shoots from the plant, shoot diameter, and height.

This is confirmed also by the basis of these results generated as a mathematical model of Sida yielding, which is based on multiple regression equation. In addition to the above-mentioned features, this model also takes into account the height of plant shoots.

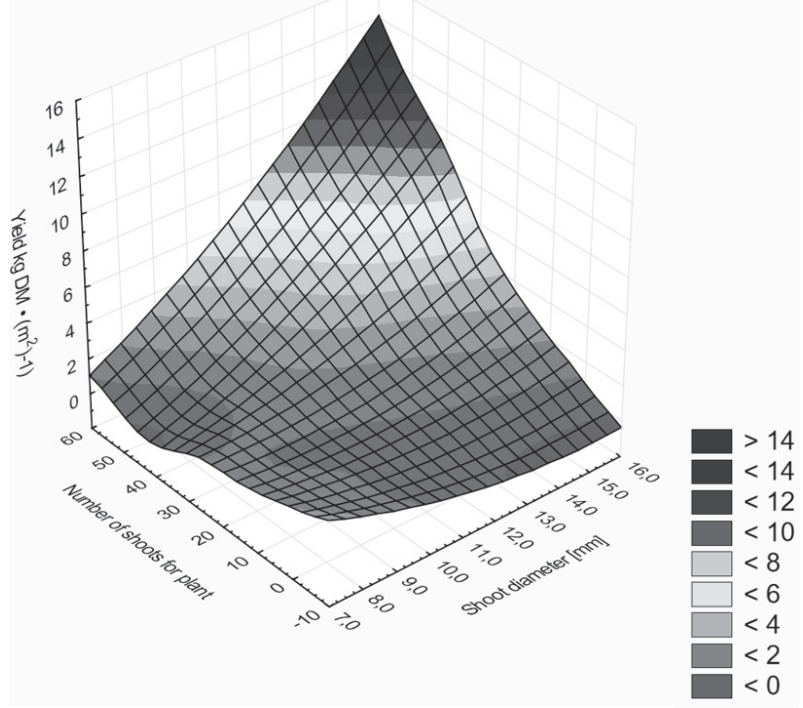

Fig. 5. Yield model for Sida hermaphrodita determined by number of stems and their diameter. 
Table 5. Results of cluster analysis (k-means method) for the soils, taking into account different criteria for allocation.

\begin{tabular}{|c|c|c|}
\hline $\begin{array}{c}\text { Criteria } \\
\text { for allocation }\end{array}$ & Data cluster I & Data cluster II \\
\hline $\begin{array}{c}\text { Yield and } \\
\text { biometric features }\end{array}$ & A, B, D, E* & C, F \\
\hline Yield & A, B, D, E & C, F \\
\hline Biometric features & A, B, C, D, E & F \\
\hline
\end{tabular}

* type of soil

$$
\begin{gathered}
y=-2.93+0.07 \cdot X_{1}+0.26 \cdot X_{2} \\
R^{2}=0.66
\end{gathered}
$$

...where: y is yield $\mathrm{kg} \mathrm{DM}\left(\mathrm{m}^{2}\right)^{-1}, \mathrm{X}_{1}$ is number of shoots for plant, and $\mathrm{X}_{2}$ is shoot diameter (mm).

To further explain the relationship between the yield of Virginia mallow and its biometric features we used modeling with neural networks, which are part of the new data mining statistical method (Figs 3-5). Analysis of the results shows that in order to achieve Sida hermaphrodita yields of 1-2 $\mathrm{kg} \mathrm{DM}\left(\mathrm{m}^{2}\right)^{-1}$, regardless of the soil, are possible when plants have the following biometric features:

$$
\begin{gathered}
\text { number of shoots per plant }=<16-24< \\
\text { shoot diameter }(\mathrm{mm})=<11-13< \\
\text { plant height }(\mathrm{m})=<2,2-2,6<
\end{gathered}
$$

These results, in addition to the nature of cognition, may serve as a benchmark for further work on selection and breeding of Virginia mallow.

Performed cluster analysis showed that the division into clusters by the criterion of yield, biometric features, and all the parameters together converges (Table 5). This allows for the conclusion that the level of obtained yield is largely determined by biometric features.

\section{Conclusion}

Following this study it was found that Sida hermaphrodita yield less on poor soil and on soils of good quality, but too heavy. This plant has best yields on good soils with proper water-air relationships. Nevertheless, good yields were also obtained on the poorer and medium-quality soils. This is particularly important from the standpoint of competition for land resources between production for food and non-food products. The obtained results show that the introduction of this plant to cultivation should not restrict the area of best quality land that could be used for food production.

Analysis of the obtained results can also conclude that, with the development of Sida hermaphrodita plantations, relationships between biometric features have changed.
Achieving yields of $1-2 \mathrm{~kg} \mathrm{DM}\left(\mathrm{m}^{2}\right)^{-1}$ is possible in the case of plants that grow from 16 to 24 shoots per stump with a diameter of $11-13 \mathrm{~mm}$ and a of height 2.2-2.6 $\mathrm{m}$.

\section{References}

1. DIAMANTIDIS N.D., KOUKIS E.G. Agricultural crops and residues as feedstock for non-food products in Western Europe. Ind. Crops Prod., 11, 97, 2000.

2. SPOONER D.M., CUSICK A.W., HALL G.E., BASKIN J.M. Observations on the distribution and ecology of Sida hermaphrodita (L.) Rusby (Malvaceae), 1985.

3. BORKOWSKA H. Yields of Virginia fanpetals and willow on good wheat soil complex (in Polish). Fragm. Agronom., 2, 41, 2007.

4. BORKOWSKA H., MOLAS R. Two extremely different crops Salix and Sida, as source of renewable bioenergy. Biomass Bioenerg., 36, 234, 2012.

5. KARLEN D.L., DITZLER C.A., ANDREWS, S.S. 2003. Soil quality: why and how? Geoderma 114, 145, 2003.

6. KOCON A., MATYKA M. Phytoextractive potential of Miscanthus giganteus and Sida hermaphrodita growing under moderate pollution of soil with $\mathrm{Zn}$ and $\mathrm{Pb}$. Journ. Food Agric. Environ., 10 (2), 1253, 2012.

7. MATHE-GASPAR G., FODO,R N., POKOVAI K., KOVACS G.J. Crop modeling as a tool to separate the influence of the soil and weather on crop yields. Phys. Chem. Earth, 30, 165, 2005.

8. MATYKA M., KUŚ J. Sida hermaphrodita L. (Rusby). In Kołodziej B., Matyka M. Editors Renewable energy sources. Agricultural Energy resources. PWRiL Poznań, 2012 [In Polish].

9. NABEL M., TEMPERTON V. M., POORTER H., LÜCKE A., JABLONOWSKI N. D. Energizing marginal soils The establishment of the energy crop Sida hermaphrodita as dependent on digestate fertilization, NPK, and legume intercropping. Biomass Bioenerg., 87, 9, 2016.

10. PODLASKI S., PIETKIEWICZ S., CHOŁUJ D., HORACZEK T., WIŚNIEWSKI G., GOZDOWSKI D., KALAJI H. M. The relationship between the soil water storage ane water use efficiency of seven energy crops. Photosynthetica, 55 (2), 210, 2017.

11. HRYNIEWICZ M., GRZYBEK A. Emission of gases produced during cultivation of Virginia mallow (in Polish). Probl. Agricult. Engine., 4 (82), 119, 2013.

12. MATYKA M. Production and economic aspects of cultivation of perennial plants for energy purposes. Monograph, IUNG-PIB Puławy, 2013 [In Polish].

13. PSZCZÓLKOWSKA A., ROMANOWSKA-DUDA Z., PSZCZÓŁKOWSKI W., GRZESIK M., WYSOKIŃSKA Z. Biomass production of selected energy plants: Economic analysis and logistic strategies. Compar. Econom. Resea., 15 (3), 77, 2012.

14. BORKOWSKA H., MOLAS R., KUPCZYK A. Virginia fanpetals (Sida hermaphrodita Rusby) cultivated on light soils; height of yield and biomass productivity. Polis J. of. Environ. Stud., 18 (4), 563, 2009.

15. NABEL M., BARBOSA D.B.P., HORSCH D., JABLONOWSKI N.D. Energy crop (Sida hermaphrodita) fertilization using digestate under marginal conditions: A dose-response experiment. Energ. Proced., 59, 127, 2014.

16. OLESZEK M., MATYKA M., LALAK J., TYS J., PAPROTA E. Characterization of Sida hermaphrodita as 
a feedstock for anaerobic digestion process. Journ. Food Agric. Environ., 3\&4, 1839, 2013.

17. STOLARSKI J.M., KRZYŻNIAK M., ŚNIEG M., SŁOMIŃSKA E., PIÓRKOWSKI M., FILIPKOWSKI R. Thermophysical and chemical properties of perennial Energy crops depending on harvest period. Int. Agrophys., 28, 201, 2014.

18. IGNATOWICZ K. The assessment usability of Virginia mallow Sida hermaphrodita for phytoremediation of soil contaminated with pesticides (in Polish). Ecolog. Engine., 45, 89, 2015.

19. KLIMONT K., BULIŃSKA-RADOMSKA Z. The posibility of using Virginia mallow plant (Sida hermaphrodita Rusby) to reclamation of post-borehole Sulphur exploitation terrains. Probl. Agricult. Engine., 1 (79), 125, 2013 [In Polish].

20. WIERZBOWSKA J., SIENKIEWICZ S., KRZEBIETKE S., STERNIK P. Content of selected heavy metals in soli and in Virginia mallow (Sida hermaphrodita) fertlilised with sewage sludge. Journ. Element., 21 (1), 247, 2016.

21. SZYSZLAK-BARGŁOWICZ J., SŁOWIK T., ZAJAC G., PIEKARSKI W. Inline plantation of virginia mallow (Sida hermaphrodita R.) as biological acoustic screen. Ann. Set Environ. Protect., 15 (1), 524, 2013.

22. CZARNECKI R., DZIURKA D., ŁECKA J. Properties of particleboard produced with use of Sida hermaphrodita Rusby. Folia. Forest. Polon., 41, 45, 2010.
23. MATYKA M., KUŚ J. Influence of soil quality for yielding and biometric features of Miscanthus x giganteus. Pol. J. Environ. Stud. 25 (1), 213, 2016.

24. KUŚ, J., NAWROCKI, S. Productivity of different soils in microplots experiments. Pam. Puław., 79, 7, 1983 [In Polish].

25. BORKOWSKA H., MOLAS R., SKIBA D. Virginia fanpetals yielding in multi-years use. Act. Agrophys., 22 (1), 5, 2015

26. CHOŁUJ D,. PODLASKI, S., PIETKIEWICZ S., WIŚNIEWSKI G. Physiological parameters determining the yield of energy crops. In Bocian P, Golec T, Rakowski $\mathrm{J}$, Editors Modern technology obtaining and energy use of biomass. Institute of Power Engineering, Warsaw, 69, 2010 [In Polish].

27. MAJTKOWSKIW.,MAJTKOWSKA G., TOMASZEWSKI B. Phytosynthetic productivity and efficiency of perennial energetic crops. In Grzybek Editor Modelling of biomass utilization for energy purpose. BIOFORSK and ITP Falenty, 2010 [In Polish].

28. ŠIAUDINIS G., JASINSKAS A., ŠARAUSKIS E., STEPONAVIČIUS D., KARČAUSKIENE D., LIAUDANSKIENE I. The assessment of Virginia mallow (Sida hermaphrodita Rusby) and cup plant (Silphium perfoliatum $\mathrm{L}$.) productivity, physicoemechanical properties and energy expenses. Energy, 93, 606, 2015. 
